\title{
Hyperoxia: Influence on Lung Mechanics and Protein Synthesis
}

\author{
Gerardo Gacad and Donald Massaro \\ From the Pulmonary Division, Veterans Administration-George Washington \\ University Medical Center, Washington, D. C. 20422
}

A BSTRACT We studied the time-course of the influence of in vivo hyperoxia on lung mechanics and on protein synthesis. After $24 \mathrm{~h}$ of exposure to greater than $98 \% \mathrm{O}_{2}$ at $1 \mathrm{~atm}$ there were no alterations in descending pressure-volume curves (air or saline) of lungs excised from $\mathrm{O}_{2}$-exposed rats compared to control rats. After $48 \mathrm{~h}$ of hyperoxia there was a decrease in lung compliance.

To study protein synthesis, as indicated by $\mathrm{L}_{-}\left[\mathrm{U}_{-}{ }^{14} \mathrm{C}\right]$ leucine incorporation into protein, lung slices were incubated with $\mathrm{L}-\left[\mathrm{U}-{ }^{14} \mathrm{C}\right]$ leucine and surface-active material then obtained by ultracentrifugation of lung homogenates. We measured radioactivity in total protein and in protein in the surface-active fraction. There were no alterations in incorporation after $12 \mathrm{~h}$ of hyperoxia. After $24 \mathrm{~h}$ of hyperoxia there were significant decreases $(P<0.05)$ in $\mathrm{L}-\left[\mathrm{U}_{-}{ }^{14} \mathrm{C}\right]$ leucine incorporation into total protein and into protein of the surface-active fraction. After $48 \mathrm{~h}$ of hyperoxia incorporation into protein of the surface-active fraction was decreased to a greater extent than incorporation into total protein, $63 \pm 4 \%$ and $75 \pm 5 \%$, respectively, $(P<0.025)$.

These studies show that hyperoxia produces a major decrease in protein synthesis, including synthesis of protein in a surface-active fraction, before the onset of any detectable changes in the static compliance of excised lungs.

\section{INTRODUCTION}

It is widely recognized that oxygen in high concentration is toxic to the lung. Prolonged exposure of animals to oxygen at partial pressures greater than are present in room air alters the lung's mechanical properties (1). These changes suggest that the surface forces of terminal lung units have increased (2). Several hypotheses have been advanced to explain these mechanical changes including the suggestion that they could be due to an

This work was presented in part at the 64th Annual Meeting of The American Society for Clinical Investigation, Inc., Atlantic City, N. J., May, 1972.

Received for publication 3 August 1972 and in revised form 23 October 1972. oxygen-induced decrease in the synthesis of lung surfaceactive lipoprotein (1). Unfortunately, little is actually known about the influence of hyperoxia on lung biosynthetic processes. Even less is known about the time relationship between alterations in the synthesis of substances likely to be components of surface-active material and alterations in lung mechanics. These considerations led us to ask two questions. First, is in vitro protein synthesis, as measured by incorporation of $\mathrm{L}-\left[\mathrm{U}-{ }^{14} \mathrm{C}\right]$ leucine into protein, altered in lungs from rats exposed to hyperoxia? If so, does this alteration in protein synthesis, with particular reference to those proteins found in a surface-active lung fraction, precede or follow detectable changes in the lung's mechanical properties?

\section{MATERIALS}

Animals. We used male Dublin Sprague-Dawley derived rats (Flow Research Animals, Inc., Dublin, Va.) which were allowed food (Wayne Lab-Blox, Allied Mills, Inc., Chicago, Ill.) and water ad lib. For exposure to oxygen they were maintained in cages and supplied by humidified oxygen from a wall outlet at 10 liters/min. The $\mathrm{O}_{2}$ and $\mathrm{CO}_{2}$ concentrations were measured every $6 \mathrm{~h}$ during an initial series of experiments and then once during every experiment using a gas chromatograph (Fisher-Hamilton Gas Partitioner, Fisher Scientific Products, Silver Spring, Md.). The $\mathrm{O}_{2}$ concentration was never found to be lower than $98 \%$ nor the $\mathrm{CO}_{2}$ concentration greater than $0.4 \%$. Control rats were kept in identical adjacent cages which were supplied by humidified compressed air from a wall outlet at 10 liters $/ \mathrm{min}$. The animals were sacrificed by exsanguination after the intraperitoneal injection of sodium pentobarbital, $30 \mathrm{mg} / \mathrm{kg}$.

Incubation of lung slices. Lungs were removed as previously described (3) and sliced at $0.3 \mathrm{~mm}$ thickness using a McIlwain tissue chopper (Brinkman Instruments, Westbury, N. Y.). Incubations were performed at $40^{\circ} \mathrm{C}$ in rubber-capped flasks containing Waymouth medium (Grand Island Biological Co., Grand Island, N. Y.), and $\mathrm{L}-\left[\mathrm{U}-{ }^{14} \mathrm{C}\right]$ leucine (New England Nuclear Corp., Boston, Mass.). The gas phase was $95 \% \quad \mathrm{O}_{2}-5 \% \quad \mathrm{CO}_{2}$ and the flasks were shaken at 90 oscillations/min. In some studies we performed "pulsechase" experiments to determine the influence of hyperoxia on the degradation of the newly synthesized protein. To do this we incubated about $100 \mathrm{mg}$ of lung slices with L$\left[\mathrm{U}-{ }^{14} \mathrm{C}\right.$ ]leucine at $40^{\circ} \mathrm{C}$ for $10 \mathrm{~min}$ but used Earle's Balanced Salt Solution (2.5 ml) (Grand Island Biological Co.) as the medium. The flasks ( 3 from each $\mathrm{O}_{2}$ and control rat) were then chilled on ice, the medium removed and 
the slices washed quickly with Waymouth medium. These slices were then reincubated in Waymouth medium (which contains $0.38 \mu \mathrm{mol}$ of $\mathrm{L}-\left[{ }^{12} \mathrm{C}\right]$ leucine without radioactive leucine at $40^{\circ} \mathrm{C}$ for 0 or $60 \mathrm{~min}$.

Isolation of a surface-active lung fraction. In experiments where we isolated surface-active material, the reactions were stopped by chilling and all subsequent procedures performed at $4^{\circ} \mathrm{C}$. The medium was removed, the slices washed quickly with cold $0.15 \mathrm{M} \mathrm{NaCl}$ and homogenized by 30 passes of a motor driven Teflon pestle in a glass homogenizing vessel. A sample of the homogenate was saved to determine the incorporation of radioactivity into crude lung protein and the remainder was centrifuged at $300 \mathrm{~g}$ for $10 \mathrm{~min}$. The remainder of the isolation procedure was as previously described (4) and represents a modification of the procedure described by Klein and Margolis (5).

Assay for radioactivity. The tissue proteins and the proteins in the surface-active lung fraction were precipitated with trichloroacetic acid (TCA), ${ }^{1}$ extracted with lipid solvents and hot TCA, and assayed for radioactivity and protein content as previously described $(6,7)$. The hot TCA-soluble material from the crude extracts was saved for measurement of DNA content relative to the amount of acid-insoluble radioactivity.

Nature of acid-soluble radioactivity. The acid-soluble material from several incubation mixtures was collected, separated from the TCA, subjected to paper chromatography and assayed for radioactivity as previously described (8). We used material from incubations of tissue from air and $\mathrm{O}_{2}$-exposed rats separately.

Chemical determinations. Protein was measured on the material not soluble in cold or hot TCA or in lipid solvents but which was soluble in $0.2 \mathrm{M} \mathrm{NaOH}$. Crystallized bovine serum albumin (Mann Research Labs., Inc., N. Y.) served as standard (9). To obtain values for protein to DNA and RNA to DNA ratios, these substances were separated and isolated in whole tissue homogenates by the alternate procedure of Schneider (10). DNA was measured using calf thymus DNA as the standard (Mann Research Labs. Inc.). RNA was measured using yeast RNA as the standard (General Biochemicals, Div. Mogul Corp., Chagrin Falls, Ohio).

To determine the amount of free leucine in the lung tissue $500 \mathrm{mg}$ (wet weight) samples of lung were homogenized in $2.5 \mathrm{ml}$ of cold water. Cold TCA was added to a final concentration of $10 \%$, the mixture was allowed to stand on ice for $30 \mathrm{~min}$ and then the mixture was centrifuged. The supernatant material was extracted with ethyl ether to remove the TCA. This extraction was continued until the $\mathrm{pH}$ of the aqueous phase rose to 6.0. Leucine was measured in the acid-soluble material by ion exchange chromatography using a Beckman Model 120C amino acid analyzer (Beckman Instruments, Inc., Fullerton, Calif. (11). DNA and RNA were determined on the cold TCA-insoluble sediment by the alternate method of Schneider (10). Lung wet to dry weight ratios were measured by weighing lightly blotted lung slices (wet weight) and then reweighing these slices every $24 \mathrm{~h}$ after placing them at $60^{\circ} \mathrm{C}$. The weight which did not change after two consecutive measurements $24 \mathrm{~h}$ apart was taken as the dry weight.

Pressure-volume measurements. The pressure-volume ( $\mathrm{P}$ V) measurements were made as described by Johnson,

${ }_{1}^{1}$ Abbreviations used in this paper: $\mathrm{P}-\mathrm{V}$, pressure-volume measurements; RER, rough endoplasmic reticulum; TCA, trichloroacetic acid.
Permutt, Sipple, and Salem (12). The lung was completely degassed in a vacuum jar. The lung was then inflated by means of a calibrated syringe. Transpulmonary pressure was measured by a Statham PM5 pressure transducer (Statham Laboratories, Hato Rey, Puerto Rico). The air volume at a transpulmonary pressure of $30 \mathrm{~cm} \mathrm{H} \mathrm{H}_{2} \mathrm{O}$ was considered as maximum lung volume. The lung appeared completely inflated at this point. Deflation was carried out, after two inflations to $30 \mathrm{~cm} \mathrm{H}_{2} \mathrm{O}$, to predetermined transpulmonary pressures, i.e. $20,15,10,5$, and $0 \mathrm{~cm} \mathrm{H}_{2} \mathrm{O}$. The lung volume at each pressure was recorded. In some experiments $\mathrm{P}-\mathrm{V}$ measurements were made using saline to inflate the lung (13).

Statistical calculations. Table II was derived from Table I. To do this we set the mean protein-specific radioactivity of the air exposed rats at $100 \%$ for each time of exposure. Each protein-specific activity from the air-exposed animals was then expressed as a percentage of this mean value and the SEM calculated from these values. This same mean protein-specific activity also served as $100 \%$ for the oxygenexposed rats for each time of exposure. Each proteinspecific activity from the oxygen-exposed animals was then expressed as a percentage of this figure and the SEM calculated from these values. The weight changes in individual animals with air or oxygen exposure were analyzed using a paired $t$ test (14). The significance of the differences between other values from these animals were tested by an unpaired $t$ test analysis (14). SE were calculated by conventional techniques. The $P$ values have the usual connotation as an index of probability.

\section{RESULTS}

Influence of in vivo oxygen exposure for $48 h$ on $\mathrm{L}-$ $\left[U-{ }^{14} \mathrm{C}\right]$ leucine incorporation into total protein and on degradation of nervly formed radioactive protein. The protein-specific radioactivity of total acid-insoluble material is greater in lungs from air-exposed animals than in lungs from oxygen-exposed animals (Fig. 1a). This difference assumes statistical significance after a $1 \mathrm{~h}$ incubation $(P<0.01)$. When the acid-insoluble radioactivity is expressed per $\mathrm{mg}$ of DNA the differences are also significant after $1 \mathrm{~h}$ incubation (Fig. $1 b) \quad(P<0.01)$. Measurements on the free leucine content of lung tissue revealed less free leucine in the $\mathrm{O}_{2}$-exposed rats (Table $\mathrm{V}$ ). When incorporation rates are corrected for the size of the pool of free leucine the differences in acid-insoluble radioactivity between lungs from air and $\mathrm{O}_{2}$-exposed rats became greater. The acidinsolvble radioactivity of the $\mathrm{O}_{2}$-exposed rats was $65 \%$ of the air-exposed rats at $30 \mathrm{~min}(P<0.025)$, and $51 \%$ of the air-exposed rats at $60 \mathrm{~min}(P<0.005)$. In other experiments where we "pulse-labeled" lung slices with $\mathrm{L}-\left[\mathrm{U}-{ }^{14} \mathrm{C}\right]$ leucine the lungs from air- and $\mathrm{O}_{2}$-exposed rats had a virtually identical fall in protein-specific radioactivity during the post-pulse hour $(14.3 \pm 3.1 \%$ and $15.4 \pm 4.0 \%$, respectively).

Time-course of the influence of in vivo oxygen exposure on the P-V relationships of excised lungs. Fig. 2 shows the influence of exposure to hyperoxia on the deflation P-V curve. After $24 \mathrm{~h}$ of exposure there were 


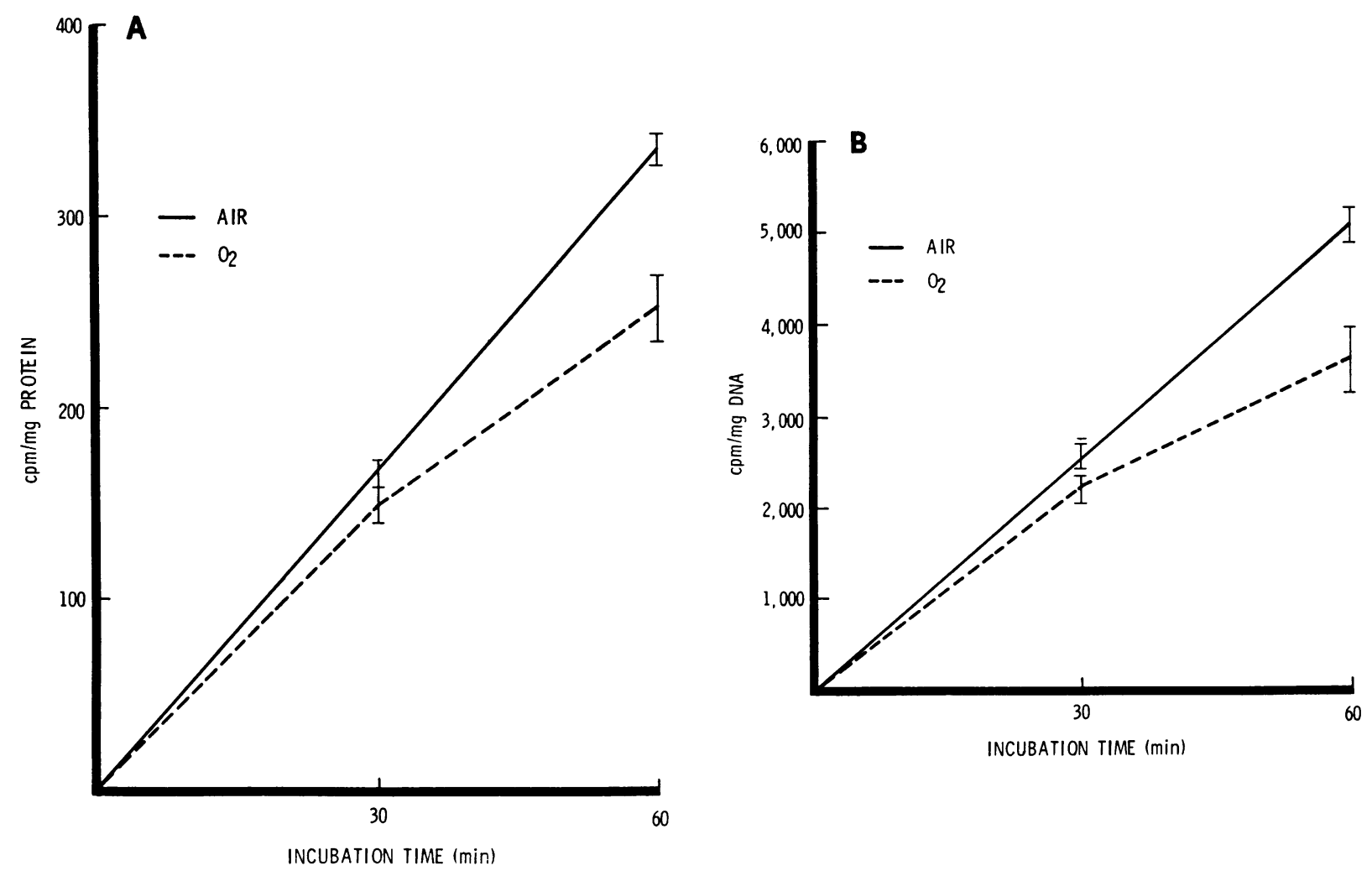

FIGURE 1 Influence of in vivo oxygen exposure on $\mathrm{L}-\left[\mathrm{U}-{ }^{14} \mathrm{C}\right]$ leucine incorporation into protein. In each experiment three replicate flasks from $\mathrm{O}_{2}$ and control rats containing about 200 $\mathrm{mg}$ of slices lung and $10 \mu \mathrm{l}$ of $\mathrm{L}-\left[\mathrm{U}-{ }^{14} \mathrm{C}\right]$ leucine $\left(9.8 \times 10^{-4} \mu \mathrm{mol}\right.$; sp act $\left.255 \mu \mathrm{Ci} / \mu \mathrm{mol}\right)$ were incubated in Waymouth medium. Mean \pm SEM are given.

no differences in the $\mathrm{P}-\mathrm{V}$ curves between the two groups when air was used to inflate the lungs (Fig. $2 a$ ) or when saline was used to inflate the lungs (not shown, five rats in each group). After $48 \mathrm{~h}$ of exposure the $\mathrm{P}-\mathrm{V}$ curve of lungs from oxygen-exposed rats was shifted to the right when compared to that of lungs from air-exposed rats (Fig. $2 b$ ).

Time-course of the influence of in vivo hyperoxia on $\left[U-{ }^{14} C\right]$ leucine incorporation into total protein and into protein in a surface-active lung fraction. We found no differences in protein-specific radioactivity after $12 \mathrm{~h}$ of in vivo hyperoxia (Table I). After $24 \mathrm{~h}$ of exposure the protein-specific radioactivity was lower in both the protein of the whole tissue homogenate and in the protein of the surface-active fraction in lungs from rats exposed to hyperoxia (Table I). Thus, we found substantial changes in $\left[{ }^{14} \mathrm{C}\right]$ leucine incorporation into protein before we detected any changes in the lung $\mathrm{P}-\mathrm{V}$ characteristics. After $48 \mathrm{~h}$ of hyperoxia there was a greater decrease in the protein-specific radioactivity of the surface-active fraction than of the protein of the whole tissue homogenate (Table I). This latter point is shown in Table II where these results are ex- pressed as a percentage of the mean protein-specific radioactivity using the mean figures for the air-exposed rats as $100 \%$ for each time interval.

Influence of hyperoxia on animal weight. There were no differences in initial weight between groups of oxygen- or air-exposed animals (Table III). Both groups gained equal amounts of weight up to $24 \mathrm{~h}$ of exposure. Thereafter, the rats exposed to hyperoxia lost weight. The rate of weight gain decreased in airexposed rats.

Influence of in vivo L-tryptophan on $\mathrm{L}-\left[U-{ }^{14} C\right]$ leucine incorporation into protein. We have previously shown that tryptophan reverses the decrease in protein synthesis by lungs from rats starved for $48-72 \mathrm{~h}$ (4). In this present study, although the animals were allowed food and water ad lib., those exposed to oxygen for $48 \mathrm{~h}$ lost weight (Table III). We therefore sought to determine if the decrease in protein synthesis in animals exposed to oxygen for $48 \mathrm{~h}$ would be altered by the administration of tryptophan. Unlike its effect on food deprived but air-exposed animals (4), tryptophan did not reverse the decrease in protein synthesis by lungs from oxygen-exposed rats (Table IV).

Oxygen and Protein Synthesis by Lung 561 

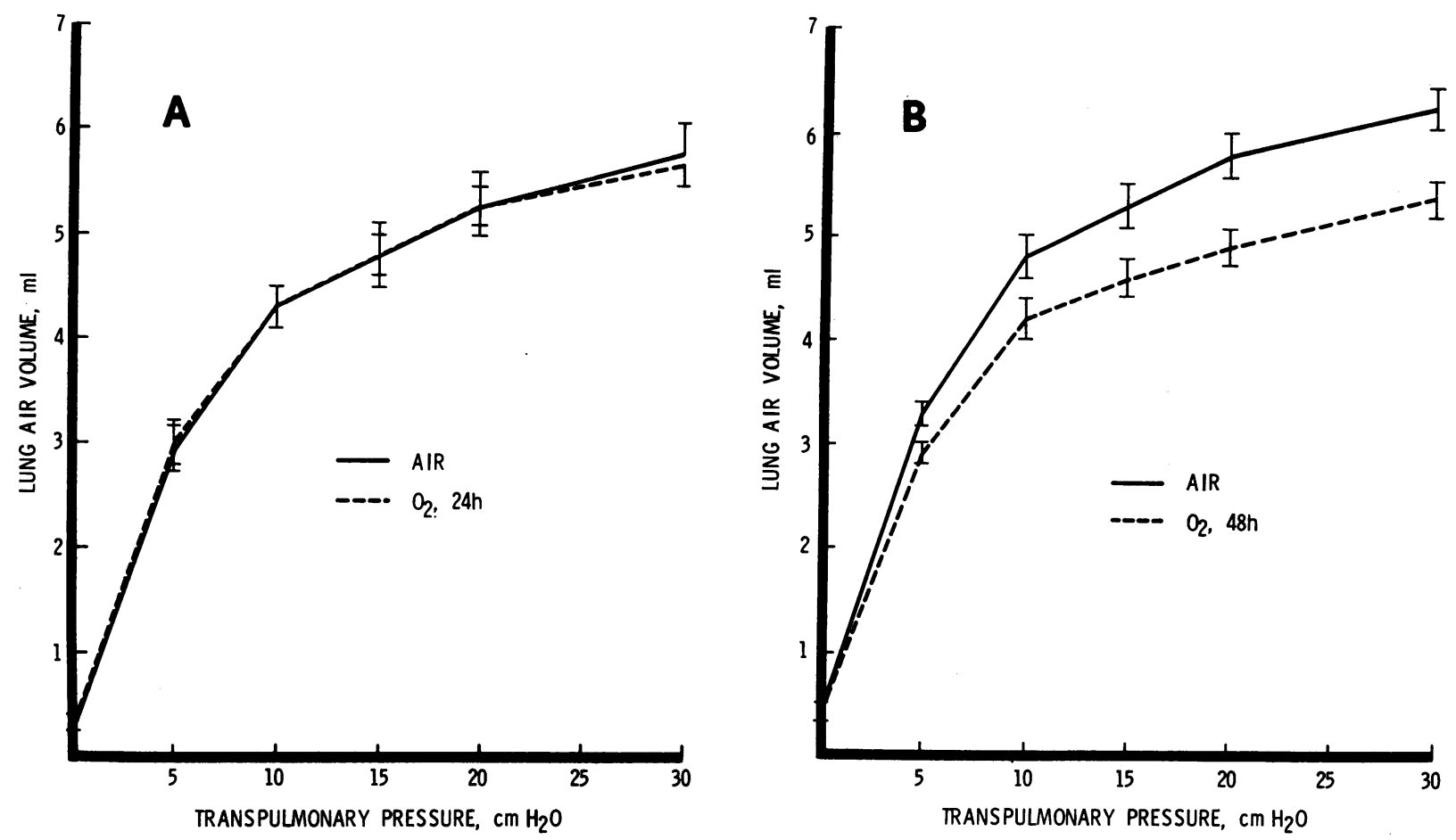

FIGURE 2 Influence of in vivo oxygen exposure on air deflation $\mathrm{P}-\mathrm{V}$ curves of excised lungs. Each curve represents five animals. Mean \pm SEM are given.

TABLE I

Influence of In Vivo Oxygen Exposure on Amino Acid Incorporation into Total Protein and into Protein of a Surface-Active Fraction by Rat Lung Slices

\begin{tabular}{|c|c|c|c|}
\hline \multirow[b]{2}{*}{ Exposure } & \multirow[b]{2}{*}{ Atmosphere } & \multicolumn{2}{|c|}{ Protein-specific radioactivity } \\
\hline & & Total & Surface-active fractior \\
\hline \multirow[t]{2}{*}{$h$} & & \multicolumn{2}{|c|}{$c p m / m g$ protein } \\
\hline & Air & $\begin{array}{c}1199 \pm 84 \\
(4)\end{array}$ & $\begin{array}{c}1952 \pm 98 \\
(4)\end{array}$ \\
\hline \multirow[t]{2}{*}{12} & $\mathrm{O}_{2}$ & $\begin{array}{c}1103 \pm 72 \\
(4) \\
\text { NS }\end{array}$ & $\begin{array}{c}1931 \pm 155 \\
(4) \\
\text { NS }\end{array}$ \\
\hline & Air & $\begin{array}{c}1101 \pm 62 \\
\text { (8) }\end{array}$ & $\begin{array}{l}1992 \pm 178 \\
(6)\end{array}$ \\
\hline \multirow[t]{3}{*}{24} & $\mathrm{O}_{2}$ & $\begin{array}{c}812 \pm 46 \\
(6)\end{array}$ & $\begin{array}{c}1559 \pm 125 \\
(4)\end{array}$ \\
\hline & & 0.005 & 0.05 \\
\hline & Air & $\begin{array}{c}1102 \pm 84 \\
(4)\end{array}$ & $\begin{array}{c}1847 \pm 82 \\
(4)\end{array}$ \\
\hline \multirow[t]{2}{*}{48} & $\mathrm{O}_{2}$ & $\begin{array}{c}832 \pm 34 \\
(7)\end{array}$ & $\begin{array}{c}1164 \pm 87 \\
(7)\end{array}$ \\
\hline & & 0.005 & 0.001 \\
\hline
\end{tabular}

In each experiment a single flask containing about $500 \mathrm{mg}$ of sliced lung tissue in $5.0 \mathrm{ml}$ of medium was incubated for 60 min with $25 \mu$ liter of $\mathrm{L}\left[\mathrm{U}_{-14}{ }^{14} \mathrm{C}\right]$ leucine $\left(2.4 \times 10^{-3} \mu \mathrm{mol}\right.$; sp act $306 \mu \mathrm{Ci} / \mathrm{mol})$. Values in parentheses indicate number of animals. Mean \pm SEM are given. NS, $P>0.05$.
Nature of acid-soluble and acid-insoluble radioactivity. All the acid-soluble radioactivity from both oxygenexposed and control rats has the same $R_{f}$ as known leucine in two different solvent systems (8).

Influence of in vivo hyperoxia on biochemical parameters in lung. Of those parameters measured (Table $\mathrm{V}$ ) only the free leucine content of lung tissue was significantly different between the two groups.

\section{DISCUSSION}

The present study has shown that lung slices from rats exposed to hyperoxia and incubated with $\left[{ }^{14} \mathrm{C}\right]$ leucine have a lower protein-specific radioactivity in the protein of the whole tissue homogenate and in the protein of the surface-active fraction than lung slices from rats exposed to compressed air. These differences become larger when corrected for free leucine content of lung tissue indicating they are not due to differences in the total level of free leucine in these tissues. However, this does not exclude the possibility that leucine pools may be compartmentalized and hence that the protein precursor pool might be different in control and $\mathrm{O}_{2}$-exposed rats (15). Indeed, a recent study has indicated that in liver, free intracellular valine exists as two distinct pools (16). One pool appears to be independent of external valine while the other pool equilibrates rapidly with the suspending medium and appears to be in continuity with sites of protein synthesis. Such in- 
TABLE II

Relative Effect of In Vivo Oxygen Exposure on Amino Acid Incorporation into Total Protein and into Protein of a Surface-Active Fraction

\begin{tabular}{ccccc}
\hline & & \multicolumn{3}{c}{ Percent of control } \\
\cline { 3 - 5 } Exposure & Atmosphere & $\begin{array}{c}\text { Total } \\
\text { radioactive } \\
\text { protein }\end{array}$ & $\begin{array}{c}\text { Surface-active fraction } \\
\text { radioactive protein }\end{array}$ \\
\hline$h$ & & & & \\
\multirow{2}{*}{12} & $\mathrm{Air}$ & $100 \pm 7$ & $100 \pm 2$ & \\
\multirow{2}{*}{24} & $\mathrm{O}_{2}$ & $92 \pm 5$ & $99 \pm 5$ & $\mathrm{NS}$ \\
& $\mathrm{Air}$ & $100 \pm 6$ & $100 \pm 9$ & \\
48 & $\mathrm{O}_{2}$ & $7 \pm \pm 5$ & $78 \pm 6$ & $\mathrm{NS}$ \\
& $\mathrm{Air}$ & $100 \pm 12$ & $100 \pm 1$ & \\
& $\mathrm{O}_{2}$ & $75 \pm 5$ & $63 \pm 4$ & 0.024 \\
\hline
\end{tabular}

The values in this table are derived from the protein-specific radioactivities in Table $\mathrm{I}$. See text for an explanation. $P$ is given for the difference between the effect of oxygen on incorporation into total protein and into protein in the surface-active fraction.

formation is not available for free amino acid pools in the lung. However, the kinetics of $\left[{ }^{14} \mathrm{C}\right]$ leucine transport from the suspending medium to acid-soluble material in lung slices and then into protein indicates that there is a very rapid equilibration of leucine in the medium with leucine serving as a precursor for protein synthesis (7). Therefore, the use of an in vitro system of lung tissue would, as in other tissues (17), diminish any potential inequality in intracellular amino acid pools. The latter would rapidly equilibrate with the much higher concentrations of amino acid in the incubating medium. The demonstration that the acid-soluble radioactivity is leucine in both the oxygen-exposed and control animals indicates this radioactive substrate did not undergo conversion to other metabolites before being incorporated into protein and hence was not diverted into other pathways to any serious degree. The similar deg-

TABLE III

Influence of Oxygen on Animal Weight

\begin{tabular}{cccccc}
\hline & \multicolumn{2}{c}{ Air } & & \multicolumn{2}{c}{$\mathrm{O}_{2}$} \\
\cline { 2 - 3 } \cline { 5 - 6 } Ewin:ure & Intial & Final & & Initial & Final \\
\hline$h$ & \multicolumn{2}{c}{$g$} & & \multicolumn{2}{c}{$g$} \\
12 & $253 \pm 13$ & $265 \pm 10$ & & $252 \pm 4$ & $264 \pm 6$ \\
& $(4)$ & $(4)$ & & $(4)$ & $(4)$ \\
24 & $262 \pm 15$ & $275 \pm 15$ & & $263 \pm 15$ & $272 \pm 14$ \\
& $(8)$ & $(8)$ & & $(6)$ & $(6)$ \\
48 & $271 \pm 15$ & $283 \pm 60$ & & $282 \pm 23$ & $268 \pm 21$ \\
& $(4)$ & $(4)$ & & $(7)$ & $(7)$ \\
\hline
\end{tabular}

Values are mean $\pm \mathrm{SEM}$. Values in parentheses indicate number of animals.
TABLE IV

Influence of In Vivo Tryptophan on Amino Acid Incorporation into Total Protein and into Protein of a Surface-Active Fraction by Lung Slices

\begin{tabular}{|c|c|c|c|c|}
\hline \multirow[b]{3}{*}{ Tryptophan } & \multicolumn{4}{|c|}{ Protein-specific radioactivity } \\
\hline & \multicolumn{2}{|c|}{ Total } & \multicolumn{2}{|c|}{ Surface-active fraction } \\
\hline & + & - & + & - \\
\hline & \multicolumn{4}{|c|}{$c p m / m g$ protein } \\
\hline Air & $\begin{array}{c}805 \pm 58 \\
\text { (4) }\end{array}$ & $\begin{array}{c}829 \pm 58 \\
(5)\end{array}$ & $\begin{array}{c}1316 \pm 229 \\
(4)\end{array}$ & $\begin{array}{c}1327 \pm 11 \\
(5)\end{array}$ \\
\hline $\mathrm{O}_{2}$ & $\begin{array}{c}602 \pm 36 \\
(5)\end{array}$ & $\begin{array}{c}688 \pm 27 \\
(5)\end{array}$ & $\begin{array}{c}786 \pm 27 \\
(5)\end{array}$ & $\begin{array}{c}900 \pm 86 \\
(5)\end{array}$ \\
\hline$P$ & 0.025 & 0.025 & 0.05 & 0.95 \\
\hline
\end{tabular}

Animals were exposed to $\mathrm{O}_{2}$ or air for $48 \mathrm{~h}$. In each experiment a single flask containing about $500 \mathrm{mg}$ of sliced lung tissue in $5.0 \mathrm{ml}$ of medium was incubated for $60 \mathrm{~min}$ with $25 \mu$ liter of $\mathrm{L}-\left[\mathrm{U}-{ }^{14} \mathrm{C}\right]$ leucine $\left(2.4 \times 10^{-3} \mu \mathrm{mol}\right.$; sp act $\left.262 \mu \mathrm{Ci} / \mathrm{mol}\right)$. Trytophan treated rats received that amino acid $(29 \mathrm{mg} / 100$ g of body weight) in $0.75 \mathrm{ml}$ of $0.2 \mathrm{M} \mathrm{NaOH}$ intraperitoneally $45 \mathrm{~min}$ before sacrifice. Control animals were given an equal amount of $\mathrm{NaOH}$ without trytophan. Values in parentheses indicate number of animals. Mean $\pm \mathrm{SEM}$ are given.

radation rates indicate the differences in proteinspecific radioactivity are not due to differences in degradation over the time studied.

Food deprivation decreases protein synthesis by some tissues (18) including the lung (4). This effect in lung and in other tissues is reversed by the in vivo administration of tryptophan. Since in the present study the

TABLE V

Influence of In Vivo Oxygen Exposure on Chemical Composition on the Lung

\begin{tabular}{|c|c|c|c|}
\hline Parameter & Air & O:., $48 \mathrm{hl}$ & $P$ \\
\hline$\%$ of dry weight & $\begin{array}{c}19.2 \pm 0.4 \\
\quad(10)\end{array}$ & $\begin{array}{c}18.0 \pm 0.6 \\
(7)\end{array}$ & NS \\
\hline mg DNA/100 mg tissue & $\begin{array}{c}0.15 \pm 0.06 \\
\quad(11)\end{array}$ & $0.14 \pm 0.04$ & NS \\
\hline $\mathrm{mg}$ protein $/ 100 \mathrm{mg}$ tissue & $\begin{array}{c}4.99 \pm 1.05 \\
\quad(11)\end{array}$ & $\begin{array}{c}4.42 \pm 0.75 \\
\quad(11)\end{array}$ & NS \\
\hline $\mathrm{mg} \mathrm{RNA} / 100 \mathrm{mg}$ tissue & $\begin{array}{l}0.53 \pm 0.10 \\
\quad(11)\end{array}$ & $\begin{array}{l}0.48 \pm 0.12 \\
\quad(11)\end{array}$ & NS \\
\hline Protein/DNA & $\begin{array}{c}36.0 \pm 3.7 \\
(11)\end{array}$ & $\begin{array}{c}32.1 \pm 3.0 \\
\quad(11)\end{array}$ & NS \\
\hline RNA/DNA & $\begin{array}{c}3.69 \pm 0.6 \\
(11)\end{array}$ & $\begin{array}{c}3.45 \pm 0.9 \\
(11)\end{array}$ & NS \\
\hline$m \mu \mathrm{mol}$ leucine/mg DNA & $\begin{array}{c}49.6 \pm 4.3 \\
(5)\end{array}$ & $\begin{array}{c}37.3 \pm 4.4 \\
(5)\end{array}$ & 0.05 \\
\hline
\end{tabular}

Values in parentheses indicate number of animals. Mean \pm SEM are given. NS, $P>0.05$.

Oxygen and Protein Synthesis by Lung 
oxygen-exposed rats ate less and lost weight, the differences in $\left[{ }^{14} \mathrm{C}\right]$ leucine incorporation into protein could have been due to food deprivation rather than to a more direct effect of oxygen on protein biosynthesis. We think this is unlikely for two reasons. First, we noted changes in protein synthesis after $24 \mathrm{~h}$ of oxygen exposure, before weight loss occurred. Secondly there was a complete failure of tryptophan to reverse the decrease in leucine incorporation in the present study after weight loss had occurred ( $48 \mathrm{~h}$ of oxygen exposure).

Our finding that $\left[{ }^{14} \mathrm{C}\right]$ leucine incorporation into protein present in a surface-active fraction is depressed to a greater extent than its incorporation into total protein is intriguing. One explanation is simply that oxygen exerts a differential degree of inhibition on $\left[{ }^{14} \mathrm{C}\right]$ leucine incorporation into lung proteins, and that mere chance was operative in the greater depression noted in the synthesis of protein in the surface-active fraction. A second possibility, which might act in concert with the first, is that oxygen increases the rate of degradation of pratein in the surface-active fraction relative to protein in the total lung homogenate thereby lowering its specific radioactivity. A third possibility is that oxygen exerts a more profound depressing effect on the synthesis of lung secretory protein, i.e. pulmonary surfactant, than it does on the synthesis of structural and nonsecretory protein. The present study does not allow us to choose among these possibilities. However, it is of some interest to consider the last explanation in the light of available information. First, it is generally accepted that secretory and nonsecretory proteins are synthesized on different intracellular organelles, the rough endoplasmic reticulum (RER) and free ribosomes, respectively, (19). Secondly, the integrity of the RER is dependent on the lipid-rich membranous endoplasmic reticulum whereas the free ribosomes are connected together by strands of messenger ribonucleic acid (mRNA). Based on the known disruptive effect of oxygen on lipid membranes (20), it is conceivable that the lipid-rich endoplasmic reticulum could be more susceptible to hyperoxia than the polysomes. Finally, it has been reported that oxygen exposure denudes the RER in the granular pneumocyte of ribosomes (21).

It is difficult to compare our results on protein synthesis with the influence of hyperoxia on other biosynthetic properties of the lung since the other studies used hyperbaric oxygenation. Thus, Newman and Naimark (22) reported that hyperoxia enhanced the in vivo incorporated of radioactive palmitate into lung phospholipids. McSherry and Gilder (23) found that the incorporation of radioactive palmitate into phospholipid per gram of lung decreased with increasing exposure to hyperbaric oxygen. Unfortunately, they did not indicate the degree of edema in these lungs and hence, one can- not make a meaningful interpretation of the incorporation figures expressed per gram of wet lung.

Beckman and Weiss (2) have shown that the lung compliance of rats exposed to $100 \%$ oxygen at $1 \mathrm{~atm}$ for $60-66 \mathrm{~h}$ is lower than that of animals exposed to room air. They concluded that this change in compliance was predominantly due to an increase in surface forces. It seems clear from the present work that in rats exposed to hyperoxia there is a decrease in protein synthesis before there is a detectable fall in compliance when measured using either air or saline to inflate the lungs. Our failure to detect mechanical changes after 24 $\mathrm{h}$ of hyperoxia is consistent with a careful stereological study of the air-blood barrier in rats, which failed to reveal any differences in its thickness after $24 \mathrm{~h}$ of hyperoxia (24).

The next obvious question is how do we relate the decrease in protein synthesis to the mechanical changes in lungs from rats exposed to hyperoxia? The answer to this question depends, at least in part, on how one interprets the finding of decreased synthesis of proteins in the surface-active fraction of lung. This fraction probably contains some proteins which are not components of the surface-active lipoprotein and hence one could rightly argue that we cannot really be sure that ["C]leucine incorporation into this specific protein is decreased. We cannot disprove this contention. However, the decreased incorporation into the surface-active fraction is associated with a decrease in the size but no change in number of the lamellar bodies (25). Substantial evidence indicates that lamellar bodies are storage sites for surfactant. We view this decrease in size as complementary evidence to the incorporation data indicating decreased synthesis of the apoprotein of the surface-active lipoprotein. If this interpretation of our data is accepted then the relationship between hyperoxia, altered protein synthesis, and changes in lung compliance can be explained at least in part. Decreased synthesis of lung surfactant would result in a decreased amount of this material available for secretion onto the alveolar surface, resulting in increase in surface forces, and hence a decrease in compliance. The time-course of these biosynthetic and mechanical changes is consistent with the postulated half-life of the phospholipid component of lung surfactant (26). An increase in alveolar surface forces could also produce pulmonary edema (27), which is an additional constant finding in oxygen toxicity (1). Thus, a decrease in surfactant synthesis could account for the mechanical and histological changes seen in oxygen toxicity. This situation could be further aggravated by capillary destruction (24) and leakage into the alveolar spaces of blood components which inactivate surfactant (28). 


\section{ACKNOWLEDGMENTS}

Supported in part by the John A. Hartford Foundation and the American Thoracic Society.

\section{REFERENCES}

1. Clark, J. M., and C. J. Lambertsen. 1971. Pulmonary oxygen toxicity: a review. Pharmacol. Rev. 23: 37 .

2. Beckman, D. L., and H. S. Weiss. 1969. Hyperoxia compared to surfactant washout on pulmonary compliance in rats. J. Appl. Physiol. 26: 700.

3. Massaro, D., H. Weiss, and G. White. 1971. Protein synthesis by lung following pulmonary artery ligation. J. Appl. Physiol. $31: 8$.

4. Gacad, G., K. Dickie, and D. Massaro. 1972. Protein synthesis in lung: influence of starvation on amino acid incorporation into protein. J. Appl. Physiol. 33: 381.

5. Klein, R. M., and S. M. Margolis. 1968. Purification of pulmonary surfactant by ultracentrifugation. J. Appl. Physiol. 25: 654.

6. Massaro, D. 1968. Alveolar cells : incorporation of carbohydrate into protein and evidence for intracellular protein transport. J. Clin. Invest. $47: 366$.

7. Massaro, D., H. Weiss, and M. R. Simon. 1970. Protein synthesis and secretion by lung. Am. Rev. Resp. Dis. 101 : 198.

8. Massaro, D., K. Kelleher, G. Massaro, and H. Yeager, Jr. 1970. Alveclar macrophages: depression of protein synthesis during phagocytosis. Am. J. Physiol. 218: 1970.

9. Lowry, O. H., N. J. Rosebrough, A. L. Farr, and R. J. Randall. 1951. Protein measurement with the Folin phenol reagent. J. Biol. Chem. 193: 265.

10. Schneider, W. C. 1956. Determination of nucleic acids in tissues by pentose analysis. Methods Enzymol. 3:680.

11. Beckman Instruction Manual. Spinco Division, Beckman Instruments, Inc., Fullerton, Calif. 5-1.

12. Johnson, J. W. C., S. Permutt, J. H. Sipple, and E. S. Salem. 1964. Effect of intra-alveolar fluid on pulmonary surface tension properties. J. Appl. Physiol. 19: 769.

13. Cook, C. S., J. Mead, G. L. Schreiner, N. R. Frank, and J. M. Craig. 1959. Pulmonary mechanics during induced pulmonary edema in anesthetized dogs. J. Appl. Physiol. 14 : 177.

14. Snedecor, G. W., and W. G. Cochran. 1969. Statistical Methods. The Iowa State University Press, Ames, Iowa. 91.
15. Kipnis, D. M., E. Reiss, and E. Helmreich. 1961. Functional heterogeneity of intracellular amino acid pool in mammalian cells. Biochim. Biophys. Acta. 51: 519.

16. Mortimore, G. E., K. H. Woodside, and J. E. Henry. 1972. Compartmentation of free valine and its relation to protein turnover in perfused rat liver. J. Biol. Chem. $247: 2776$.

17. Hanking, B. M., and S. Roberts. 1964. Influence of amino acid levels on protein synthesis in vitro. Nature (Lond.). 204 : 1194.

18. Sidransky, H., D. S. R. Sarma, M. Bongiono, and E. Verney. 1968. Effect of dietary tryptophan on hepatic polyribosomes and protein synthesis in fasted mice. $J$. Biol. Chem. 243 : 1123.

19. Ganoza, M. C., and C. A. Williams. 1969. In vitro synthesis of different categories of specific protein by membrane-bound and free ribosomes. Proc. Natl. Acad. Sci.U.S. A. 63: 1370 .

20. Robinson, J. D. 1965. Structural changes in microsomal suspensions. II. Formation of lipid peroxides. Arch. Biochem. Biophys. 112: 170.

21. Yamamoto, E., M. Wittner, and R. M. Rosenbaum. 1970. Resistance and susceptibility to oxygen toxicity by cell types of the gas-blood barrier of the rat lung. Am. J. Pathol. 59 : 409.

22. Newman, D., and A. Naimark. 1968. Palmitate- ${ }^{14} \mathrm{C}$ uptake by rat lung: effect of altered gas tensions. Am. J. Physiol. 214: 305.

23. McSherry, C. K., and H. Gilder. 1970. Pulmonary oxygen toxicity and surfactant. In Proceedings of the Fourth International Conference on Hyperbaric Medicine. J. Wada and T. Iwa, editors. Igaku Shoin Ltd., Tokyo. 10.

24. Kistler, G. S., P. R. B. Caldwell, and E. R. Weibel. 1967. Development of fine structural damage to alveolar and capillary lining cells in oxygen-poisoned rat lung. J. Cell. Biol. 32: 605.

25. Massaro, G. D., and D. Massaro. 1973. Hyperoxia : a stereological ultrastructural examination of its influence on cytoplasmic components of the pulmonary granular pneumocyte. J. Clin. Invest. 52: 566.

26. Tierney, D. F., J. A. Clements, and H. S. Tranhan. 1967. Rates of replacement of lecithin and alveolar instability in rat lungs. Am. J. Physiol. 213: 671 .

27. Green, D. G. Pulmonary edema. 1965. Handb. Physiol. 2: 1585

28. Tierney, D. F., and R. P. Johnson. 1965. Altered surface tension of lung extracts and lung mechanics. $J$. Appl. Physiol. 20(Sec. 3) : 1253. 